\title{
Survival analysis of sow longevity and lifetime reproductive performance - Review
}

\author{
${ }^{1}$ Angéla Soltész $-{ }^{2}$ Ágnes Baginé Hunyadi $-{ }^{2}$ Szilvia Kusza $-{ }^{1}$ Péter Balogh \\ University of Debrecen \\ ${ }^{1}$ Faculty of Economics, Institute of Sectoral Economics and Methodology, Debrecen, Hungary \\ ${ }^{2}$ Faculty of Agricultural and Food Sciences and Environmental Management, \\ Institute of Animal Science, Biotechnology and Nature Conservation, Debrecen, Hungary \\ soltesz.angela@econ.unideb.hu
}

\begin{abstract}
SUMMARY
Sow longevity plays an important role in economically efficient piglet production. Improving sow longevity results increase in the productivity and profitability of a sow herd. Longevity is a complex trait with many factors that can contribute to a sow having a long and productive life. Not only the sow's genetics, but also nutrition, environment and the management policies are important. In addition, the removal of non-productive sows along with the introduction of replacement gilts is an essential part of maintaining herd productivity at a constantly high level. The objective of this paper was to summarize the current knowledge about the sow longevity and lifetime performance values, as well as, discusses the survival analysis methods for sow longevity traits. This method can estimate the hazard rate indicating proportional risk of sows being culled at any given time, in addition, it is able to investigate the effects of different factors on longevity. Identifying factors that influence the longevity could assist many commercial pig producers in becoming more efficient.
\end{abstract}

Keywords: sow, longevity, lifetime performance, survival analysis

\section{ÖSSZEFOGLALAS}

A tenyészkocák élettartama jelentös szerepet játszik a gazdaságilag hatékony malac elöállitásban. Az élettartam növekedése növeli a kocák termelékenységét és ezáltal a telep jövedelmezöségében is javulást eredményez. Az élettartamot, mint komplex jellemvonást, számos tényezö befolyásolja, hozzájárulva a kocák hosszú és produktív termelési idejéhez. A befolyásoló tényezök között nemcsak a genetika, hanem a takarmányozás, a tartáskörülmények valamint a menedzsment munkája is döntö szerepet játszik. Emellett a folyamatosan magas szintü termelés fenntartásához nélkülözhetetlen a nem-termékeny kocák leselejtezése is és helyükre új süldök beállitása. Jelen tanulmány célja a kocák élettartamára és életteljesitmény mutatóira vonatkozó aktuális ismeretek összefoglalása, valamint a túlélés elemzés, mint élettartam vizsgálatára alkalmas módszer jelentöségének ismertetése. A módszer egyrészt becslést ad a kockázati rátára, mely annak a valószinüségét adja meg, hogy adott idővel a termelésbe állitás után a koca selejtezésre kerül. Másrészt számszerü értékelést ad az élettartamot befolyásoló tényezők hatására vonatkozóan is. E tényezök alaposabb ismerete segitséget nyújthat a termelök számára hatékonyabbá válásukban.

Kulcsszavak: tenyészkoca, élettartam, életteljesitmény, túlélési analizis

\section{INTRODUCTION}

Longevity of adult females is a trait with a significant effect on swine farm profitability (Hoge and Bate, 2011) and can be also considered as an important indicator of animal welfare (Fernandez de Sevilla et al., 2008). Due to the importance, sow longevity has been the subject of several researches in relation with both productive (Yazdi et al., 2000a; Serenius and Stalder, 2004; Tarrés et al., 2006a) and morphological characters (Tarrés et al., 2006b). Results of these studies have shown that long lifetime production and low culling rates in swine herds have substantial economic benefits that is the consequence of decreasing replacement costs and greater proportion of mature sows that have reached their maximum productivity (Hoge and Bates, 2011).

Improving economic efficiency is good reasons to investigate what factors might contribute to opportunities to improve sow longevity. In the scientific literature several factors were examined how influence the sow's lifetime and thus the efficiency of sow's production. The most studies focused on the effect of genetics, nutrition, housing, season or management policies including breeding system, culling system and feeding program. Moreover researchers examined also the effect of several gilt's trait like age at first mating and farrowing, body condition, length of lactation etc. on sow longevity. The herdsman considers the sow's parity number, production, reproductive status, health status and herd structure when he decides that whether a sow will be removed (Engblom et al., 2008). A better knowledge of these factors would be useful when providing practical recommendations for the management of sows in order to increase their productive lifetime.

Reliable breeding value estimation is a base for efficient selection for improving all economically important swine production traits. Alternatives for breeding value estimation of sow longevity can roughly be divided into two types. The first type uses different modifications of linear model analysis, whereas the second type uses survival analysis (Serenius and Stalder, 2004).

Ducrocq (1987) has proposed a general strategy based on survival analysis as an adequate method for the evaluation of the length of productive life measurements. This approach is able to manage for censored observations (the cases in which the event has not yet occurred or is not known to have occurred), non-normal distribution and model time-dependent effects. 
In analysing survival data, two functions that are dependent on time are of particular interest: the survival function and the hazard function (Kaplan and Meier, 1958). The survival function is defined as the probability of surviving at least to a given time. The hazard function is the conditional probability of removal (culling or death) at a given time having survived to that time. The log rank test is used to test whether there is a difference between the survival times of different groups but it does not allow other explanatory variables to be taken into account.

In particular, a semiparametric proportional hazards model (Cox, 1972) is usually used to investigate the influence of different covariates on the risk of removal. Cox model is analogous to a multiple regression model and enables the difference between survival times of different groups of sows to be tested while allowing for other factors. In this model, the response variable is the hazard. The hazard is the probability of removal given that sows have survived up to a given point in time, or the risk for removal at that moment.

The examination of sow longevity using survival analysis can be considered frequent in the scientific literature (Jorgensen and Sorensen, 1998; Brant et al., 1999; Yazdi et al., 2000b; Serenius and Stalder, 2004; Tarres et al., 2006ab; Engblom et al., 2008; Fernandez de Sevilla et al., 2009; Hoving et al., 2011). Despite this fact, only very few Hungarian researchers have been dealing with survival analysis in pigs (Nagy et al., 2002; Balogh et al., 2015).

The aim of this study was to provide a review of current scientific knowledge of factors influencing sow longevity and lifetime reproductive performance based on methodology of survival analysis.

\section{DEFINITIONS OF SOWS LONGEVITY}

The studies in the literature indicate that sow longevity is a complex trait, and even the definition of sow longevity is variable depending on the researcher and research objective. Some definitions are based more on production efficiency (lifetime piglets born alive per parity, annualized lifetime pigs weaned), while others are more time dependent (parity at removal, length of productive life).

Generally, longevity is an example of time-to-event data, with time being the number of days (or other time unit) that a sow remains in the herd and the event being the removal (culling or death) from the herd. The productive lifetime can described as the length of time from some initial event like herd entry, first mating, first farrowing, etc. until the animals is culled from the herd or is a mortality. However, clear consensus has not been reached in the scientific literature regarding the definition of longevity.

Ducrocq and Sölkner (1998) described that longevity of sows summarizes the effects of functional traits on the ability to delay involuntary culling. Yazdi et al. (2000b), and Tarrés et al. (2003, 2006ab) considered longevity as number of days from first farrowing to removal from the herd. Similarly, Engblom et al. (2008) calculated the number of days between first farrowing and removal or termination of data collection, noted as productive life. Other researcher (Rodriguez-Zas et al.,
2003) determined two indicators of sow longevity namely herd life and productive days. Herd life was defined as the total number of days from first service (regardless of success) until removal from the herd. While, productive days were calculated as the total number of days the sow gestated and lactated until removal from the herd. Same as definition of herd life, Fernandez de Sevilla et al. (2008) defined sow longevity as the time interval between the first fertile mating and culling or death. In addition, Sobczyńska et al. (2014) defined the length of productive life as the number of days between birth and last farrowing. Similarly, Gou et al. (2001) calculated the length of productive life as number of days elapsed between the sow's herd entry date and the date of culling.

Definition of longevity based on production efficiency were determined as lifetime prolificacy. Guo et al. (2001) defined lifetime prolificacy as the number of pigs born alive produced during the sow's life, whilst Serenius and Stalder (2004) considered as the total number of pigs produced in lifetime of a sow. Others combined a measure of productivity into a continuous measure of time as pigs born alive per day of life (Holder et al., 1995).

Six different definitions of longevity were developed by Hoge and Bates (2011). Length of productive life was determined as the number of days from the date of first farrowing to the date of culling or censoring. Similarly, the lifespan of a sow was determined as the maximum parity she completed before removal. Lifetime prolificacy was determined as the number of piglets (born alive) produced during the length of productive life. Stayability has been defined as a binary trait measuring whether a sow has survived in a herd until some defined fixed parity or time. From this definition, 2 different discrete measures were determined using production-based thresholds. They were the ability of a sow to achieve 4 parities before removal and the ability of a sow to produce 40 pigs before removal.

Sum up, we can see that sow longevity can be defined in several ways and each definition has somewhat different interpretation.

\section{FACTORS AFFECTING SOW LONGEVITY}

In the scientific literature several studies determined that a better knowledge of the effects that influenced sow longevity and reproductive efficiency are important for producers managing commercial herds. As a measurement of sow longevity, the mean parity of culled females has been used in the most cases. Moreover, length of productive life in days, lifetime pigs born and/or weaned per culled females and culling rate have also been used for longevity measurements (Stein et al., 1990).

From an economic perspective, estimates for optimal sow herd life have ranged from four to eight parities (Rodriguez-Zas et al., 2006, Abell et al., 2010), and according to Lucia et al. (2000) and Stalder et al. (2003), at least three litters should complete a sow before there is positive cash flow for the producer

In last decades can be observed an excessive proportion of sows are replaced at early parities before reaching peak productivity. The reported average 
parity number at removal is fewer than five litters, with a range from 3.1 to 4.6 (Rodriguez-Zas et al., 2003, Hoge and Bates, 2011) and nearly one-third of the females that entered the herd were removed as gilts (Knauer et al., 2011).

Rodriguez-Zas et al. (2003) assuming an average of 2.35 parities per year, and that four parities are required to recuperate the investment cost, a sow must remain in the herd for approximately $600 \mathrm{~d}$. The probabilities of reaching this age ranged between 0.31 and 0.48 . This range suggests that most sows are likely to be culled before recuperating the investment cost.

Tarres et al. (2006b) published that average length of productive life of purebred Large White sows in Switzerland (602 d) is similar to the average productive life of Landrace sows in Sweden (617 d; Yazdi et al., 2000a) and Large White $\times$ Landrace crossbred sows in France (Le Cozler et al., 1998), whereas Brandt et al. (1999) found a higher average length $(880 \mathrm{~d})$ for crossbred sows in weaner production herds in Germany. This difference may be due to the different type of herd. However, Engblom et al. (2008) found a lower average length from first farrowing $(579 \mathrm{~d})$ for Swedish crossbred sows. In addition, Hoge and Bates (2011) described an average length of productive life for Yorkshire females $488.8 \mathrm{~d}$, with a mean parity at removal of 3.5. Throughout their productive life cycle, females produced on average 34.9 pigs, with an average age at first farrowing of $366.2 \mathrm{~d}$.

\section{Genetics}

Important differences in genetic lines were observed that could be translated in economic benefits, provided that sows remained in the herd for period sufficient to recover the initial investment costs.

Rodriguez-Zas et al. (2006) examined 8 genetic line presenting significant effect on sow longevity. Sows from the Large White $\times$ Hampshire genetic line had a $20 \%$ greater chance of being removed than sows from the Camborough 15 genetic line. In addition, based on the survival curves was shown that the Large White $\times$ Hampshire genetic lines provided the worst herd life since over $50 \%$ of sows would be removed by end of the third parity. Xue et al. (1997) also reported a significant effect of genetic line on longevity. The most extreme genetic lines differed in herd life by $158 \mathrm{~d}$, or approximately one parity. The results of studies suggest that sow longevity could be improved by replacing a low-longevity genetic line with another genetic line with higher expected longevity.

\section{Age at first farrowing}

Sow's age at first farrowing show a significant effect on the risk of being culled and thus on the longevity. It was detected, that survivability increased with the precocity at first farrowing. Engblom et al. (2008) reported that sows of 14 months or older at their first farrowing had a 16\% greater hazard for removal than sows that were 12 months at their first farrowing. This finding agrees with other studies which have reported that gilts that reach puberty at an earlier age and were first mated at a younger age, or that farrowed at a younger age have improved reproductive performance or longevity (Tholen et al., 1996; LeCozler et al., 1998;
Yazdi et al., 2000ab; Stalder et al., 2004; Serenius and Stalder, 2007; Engblom et al., 2008; Patterson et al., 2010, Hoge and Bates, 2011; Fernandez de Sevilla et al., 2008).

Moreover, Schukken et al. (1994) hypothesized that gilts with an inherent problem of fertility became pregnant at older ages and therefore suffered a greater risk of culling. Sterning (1996) also demonstrated that gilts that reached puberty at a later age had longer intervals from weaning to estrus and a greater risk of not coming on heat than those reaching puberty at a younger age. On the other hand, Yazdi et al. (2000b) reported an increase of death risk with heavier gilts at first insemination, which may be related to older gilts at first insemination and therefore longer ages at first farrowing. According to these results, it would be recommendable to select gilts that reach puberty earlier in order to increase overall longevity.

\section{Parity - number of pigs}

Parity was found one of the most important factor on longevity which hazard ratio increased for older parities. Engblom et al. (2008) published that compared with sows in parity 1 , sows in parities 2 to 7 have a lower hazard for removal, whereas sows in parity 8 and above have a greater removal hazard. The high removal risk for first-parity sows indicates that sows that cannot cope with the production system are sorted out. The greater risk found in older parities agrees with results of Tarres et al. (2006a). They found that the increase is moderate for the first 3 parities and stronger later, especially for the last ones: a sow with 10 parities have over 4 times greater risk of being culled than first parity sows. However, it is obvious that all sows eventually will be removed, resulting in a high removal hazard for the last parities.

Sow survivability increase with the number of piglets born, as previously reported. Engblom et al. (2008) found that sows with a litter size of 9 piglets or fewer have a 24 to $60 \%$ greater hazard for removal than those with litters of 12 to 13 piglets. Similarly, Hoge and Bates (2011) also published that sows that had more pigs born alive and fewer stillborn fetuses tend to have a decreased risk of being culled. In particular, sows that have one more pig born alive in their first litter have a decreased relative culling rate, which ranged from $1.4 \%$ to $10 \%$. In addition, according to Guo et al. (2001) study, for each additional piglet born alive per parity, a sow remained about five days longer in the nucleus herd.

Similarly, the number of weaned piglets has an important effect on longevity, reported by Tarres et al. (2006a). They found, that the risk of culling increase as fewer piglets are weaned. If a sow in the first 3 parities wean more than 10 piglets, there is a probability between 85 and $90 \%$ that she would farrow again. As the number of weaned piglets decrease below 10 piglets, these percentages decrease from $80 \%$ to less than $50 \%$. If no piglet is weaned, there is a very low probability that the sow would farrow again. So these percentages are lower for later parities.

The increased removal hazard for sows with a small litter found in the studies agrees with previous studies (Friendship et al., 1986; Brandt et al., 1999; Yazdi et al., 2000a). 


\section{Reproductive cycle}

Study of Engblom et al. (2008) examining the reproductive cycle of sows found that days after farrowing and days between weaning and farrowing have significant effect on sow longevity. They reported that the hazard for removal is greater 30 to $40 \mathrm{~d}$ after farrowing than in other periods of the reproductive cycle. The pattern of overall removal during the reproductive cycle shown that herdsmen perform most of the removals within a short period after weaning (planned culling), presumably to keep the number of nonproductive days as low as possible. Other studies also have shown that most animals are removed shortly after weaning (Brandt et al., 1999) and that the risk for removal is greatest after weaning (Tarres et al., 2006a).

Similarly, days between weaning and farrowing play an important factor in sow longevity. Engblom et al. (2008) found that intervals of 120 to $122 \mathrm{~d}$ between weaning and next farrowing result in a lower hazard for removal than shorter or longer intervals. They also presented that sows with a 120 - to 122-d interval showed estrus, were inseminated within 5 to $7 \mathrm{~d}$ after weaning, and became pregnant at this first mating. However, intervals longer than $137 \mathrm{~d}$, indicating at least one return to estrus, resulted in at least a $50 \%$ greater hazard for removal than that found for 120- to $122-d$ intervals. This high level of risk for removal is probably the effect of the batchwise production system practiced in all the herds investigated. In batchwise production, sows returning to estrus are difficult to fit into another batch, especially in herds with long intervals between batches. In a previous study of this material, return to estrus accounted for almost $20 \%$ of overall removal (Engblom et al., 2007).

Moreover, Fernandez de Sevilla et al. (2008) found that the survival curve suffer a fall at approximately $135 \mathrm{~d}$ after first fertile mating, coinciding with weaning date of the litter. In a similar way, Yazdi et al. (2000a) reported an increase in the risk of culling after weaning for the first 3 litters.

\section{Farrowing month}

Using the survival analysis, Engblom et al. (2008) published the impact of farrowing month on longevity. They found that compared with July, the hazard for removal is greater in January and September, but it is less in March and December. The low hazard for sow removal in December may be because the slaughter plants prioritize fattening pigs over sows during that month. Instead, these sows are slaughtered the month after, which explains the greater hazard in January.

\section{Housing system}

Related to the housing system, floor type and type of bedding are very important because they influence the animal welfare, and thus affect the production significantly (Engblom et al., 2007). Examining the different floor type, Cameron (2012) found that a high prevalence of different leg problems (such as foot and limb disorders) may be linked for sows kept on concrete floors, with minimal or no bedding system. In other hand, Heinonen et al. (2006) reported that a high risk factor for lameness may be observed especially for slatted floors. In particular, culling due to leg problems for sows kept on slatted floor were 1.39 times higher hazard ratio than for sows kept on solid floor with straw (Balogh et al., 2015). Similarly, Pluym et al. (2013) summarized that the group-housing of gestating sows on fully or partly slatted concrete floors without bedding is undoubtedly associated with claw problems.

The consequence of claw problems is the lameness that can affect the performance of sows and thus indirectly lead to sow removals (Anil et al., 2009). Balogh et al. (2015) published that the hazard ratio of culling due to reproductive problems was 1.34 times higher for sows kept on slatted flooring system than kept on bedding solid floor.

A possible solution may be group-housing on deep litter based on straw, which has been reported to reduce the incidence and severity of claw lesions (Gjein and Larssen, 1995; Ehlorsson et al., 2002; Kilbride et al., 2010).

\section{Body condition}

There are several studies that examined the effect of different body condition traits on sow longevity in which the impact of backfat thickness was the most significant. The result of these studies shows a positive association between backfat thickness and sow survival (Tholen et al., 1996; Lopez-Serrano et al., 2000; Tarres et al., 2006b), although excessive backfat thickness could impair reproductive performance and therefore increase the culling rate due to low productivity. Fernandez de Sevilla et al. (2008) published that the optimal interval of backfat thickness at the end of the growing period was between 16 and $19 \mathrm{~mm}$ in Duroc population. However, sows with backfat thickness of more than $19 \mathrm{~mm}$ showed a higher risk of culling due to low productivity. This optimal interval fits with the results reported by Tarres et al. (2006b), although they registered backfat thickness at first farrowing. Hoge and Bates (2011) also found significant effect of backfat thickness on sow longevity. They estimated negative hazard coefficients for backfat thickness, indicated that fatter gilts within a contemporary group tended to have a decreased risk of being culled. Additionally, the estimated hazard coefficients for DY were negative, indicating that slower growing gilts within a contemporary group tended to have a decreased risk of being culled. The hazard ratios for both covariates revealed that with a 1-unit change, the risk of being culled decreased anywhere from 6.7 to $15.8 \%$, depending on the definition of longevity.

In addition, Stalder et al. (2005) reported that females from the fattest group ( $\geq 25.0 \mathrm{~mm}$ ) produced more piglets born alive than sows from intermediate backfat classes. These studies collectively support that increased backfat amounts in replacement gilts favor a longer, more productive herd life. Thus, in order to optimize sow longevity, backfat thickness must be monitored at the end of the growing period, avoiding values not only of less than $16 \mathrm{~mm}$, but also those greater than $19 \mathrm{~mm}$.

\section{Exterior traits}

The exterior traits like teat condition and leg conformation have a moderate influence on risk of culling compared with other factors when they are analysed separately, reported by Tarres et al. (2006b). They found that the combinations of nonoptimal 
levels for the different exterior traits considerably increased the hazard.

Examining the number of teats it was shown that the risk of culling increased as the number of good teats was reduced (Tarres et al., 2006b). In particular, sows with 13 or less good teats had 1.347 times greater risk of being culled and a lower survival curve than sows with 14 and more good teats. Moreover, the predicted life expectancy of sows with 13 or less good teats is only $459 \mathrm{~d}$, whereas for the other sows, it is close to 600 d. Fernandez de Sevilla et al. (2008) published similar results indicated that a bad teat condition increased the risk of elimination with a hazard ratio of 2.283, while they did not found significant differences between regular and good teat condition.

Similarly, survivability decreases with poor leg conformations reported by López-Serrano et al. (2000), Serenius and Stalder (2004), and Tarrés et al. (2006b). Fernandez de Sevilla et al. (2008) analysed specific leg defects in Duroc and Landrace sows and they stated that abnormal hoof growth impaired survival probability with a hazard ratio of close to 2 . Results of Tarres et al. (2006b) also published that the extreme values of feet and leg scores are unfavourable to longevity. For example, sows with an X-O rear leg score of 2 had 1.4 times greater risk of being culled than sows with an intermediate score. Thus, their survival function is lower with an average productive life of 449 d compared with $602 d$ for the optimal score. In addition, they found that sows at the optimum score 4 for the size of inner claws rear leg score had 0.83 times less risk of being culled than sows with scores 2 and 3 .

\section{CONCLUSIONS}

To maximize profitability of the breeding herd it is important to focus on the lifetime traits. This review provided an understanding of the factors influencing sow longevity.

Studies published focus on the economics of sow longevity and the reasons sows are removed from the breeding herds, as well as genetic, housing system, reproductive performance and other factors that contribute sow longevity. Based on these it can be suggest that traits such as parity number at removal, the total number of piglets born during a sow's lifetime and the ability to produce two or more litters are ways of selecting for longevity. In addition, a selection for conformation traits scored on gilts by utilizing phenotypic records can also contribute to a better longevity in sows.

Economical characterization of sow longevity can be used to improve the productivity, economic efficiency, and well-being of sow breeding herds.

\section{REFERENCES}

Abell, C. E.--Jones, G. F.-Stalder, K. J.-Johnson, A. K. (2010): Using the genetic lag value to determine the optimal maximum parity for culling in commercial swine breeding herds. The Professional Animal Scientist. 26: 404-411.

Anil, S.-Anil, L.-Deen, J. (2009): Effect of lameness in pigs in terms of 'five freedoms'. Journal of Applied Animal Welfare Science. 12: 144-145

Balogh, P.-Kapelanski, W.-Jankowiak, H.-Nagy, L.-Kovács, S.Huzsvai, L.-Popp, J.-Posta, J.-Soltész, A. (2015): The productive lifetime of sows on two farms from the aspect of reasons for culling. Annals of Animal Science. 15. 3: 747-758.

Brant, H.-von Brevern, N.-Glodek, P. (1999): Factors affecting survival rate of crossbred sows in weaner production. Livestock Production Science. 57. 2: 127-135.

Cameron, R. (2012): Integumentary system: skin, hoof and claw. [In: Zimmerman et al. (eds.) Diseases of Swine.] Wiley-Blackwell. West Sussex. 264-269.

Cox, D. R. (1972): Regression models and life tables. Journal of the Royal Statistical Society. Series B (Methodological). 34. 2: 187-220.

Ducrocq, V. P. (1987): An analysis of length of productive life in dairy cattle. PhD dissertation. Cornell University. Ithaca. NY. USA.

Ducrocq, V.-Sölkner, J. (1998): The Survival Kit-V3.0. A package for large analyses of survival data. Proceedings - Presented at 6 . World congress on genetics applied to livestock production. Armidale. University of New England. 447-448.

Ehlorsson, C. J.-Olsson, O.-Lundeheim, N. (2002): Investigations of housing and environmental factors affecting the claw health in group housed dry sows. Svensk Veterinärtidining. 54: 297-304.

Engblom, L.-Lundeheim, N.-Dalin, A. M.-Andersson, K. (2007): Sow removal in Swedish commercial herds. Livestock Science. 106: 76-86.
Engblom, L.-Lundeheim, N.-Strandberg, E.-Schneider, M.-Del, P.Dalin, A. M.-Andersson, K. (2008): Factors affecting length of productive life in Swedish commercial sows, Journal of Animal Science. 86: 432-441.

Fernández de Sevilla, X.-Fábrega, E.-Tibau, J.-Casellas, J. (2008): Effect of leg conformation on survivability of Duroc, Landrace, and Large White sows. Journal of Animal Science. 86: 2392-2400.

Fernàndez de Sevilla, X.-Fàbrega, E.-Tibau, J.-Casellas, J. (2009): Competing risk analyses of longevity in Duroc sows with a special emphasis on leg conformation. Animal. 3. 3: 446-453.

Friendship, R. M.-Wilson, M. R.-Almond, G. W.-McMillan, I.Hacker, R. R.-Pieper, R.-Swaminathan, S. S. (1986): Sow Wastage: Reasons for and Effect on Productivity. Canadian Journal of Veterinary Research. 50: 205-208.

Gjein, H.-Larssen, R. B. (1995): Housing of pregnant sows in loose and confined systems - a field study 3 . The impact of housing factors on claw lesions. Acta Veterinaria Scandinavica. 36: 443-450.

Guo, S. F.-Gianola, D.-Rekaya, R.-Short, T. (2001): Bayesian analysis of lifetime performance and prolificacy in Landrace sows using a linear mixed model with censoring. Livestock Production Science. 72. 3: 243-252.

Heinonen, M.-Oravainen, J.-Orro, T.-Seppa-Lassila, L.-Ala-Kurikka, E.-Virolainen, J.-Tast, A.-Peltoniemi, O. A. T. (2006): Lameness and fertility of sows and gilts in randomly selected loose-housed herds in Finland. Veterinary Research. 159: 383-387.

Hoge, M. D.-Bates, R. O. (2011): Developmental factors that influence sow longevity. Journal of Animal Science. 89: 1238-1245.

Holder, R. B.-Lamberson, W. R.-Bates, R. O.-Safranski, T. J. (1995): Lifetime productivity in gilts previously selected for decreased age at puberty. Animal Science. 61: 115-121. 
Hoving, L. L.-Soede, N. M.-Graat, E. A. M.-Feitsma, H.-Kempa B. (2011): Reproductive performance of second parity sows: Relations with subsequent reproduction. Livestock Science. 140. 1-3: 1-7.

Jorgensen, B.-Sorensen, M. T. (1998): Different rearing intensities of gilts: II. Effects on subsequent leg weakness and longevity. Livestock Production Science. 54. 2: 167-171.

Kaplan, E. L.-Meier, P. (1958): Nonparametric Estimation from Incomplete Observations. Journal of the American Statistical Association. 53. 282: 457-481.

Kilbride, A. L.-Gillman, C. E.-Green, L. E. (2010): A cross sectional study of prevalence and risk factors for foot lesions and abnormal posture in lactating sows on commercial farms in England. Animal Welfare. 19: 473-480.

Knauer, M. T.-Cassady, J. P.-Newcom, D. W.-See, M. T. (2011): Phenotypic and genetic correlations between gilt estrus, puberty, growth, composition, and structural conformation traits with first-litter reproductive measures. Journal of Animal Science. 89. 4: 935-942.

Le Cozler, Y.-Dagorn, J.-Lindberg, J. E.-Aumaitre, A.-Dourmad, J. Y. (1998): Effect of age at first farrowing and herd management on long-term productivity of sows. Livestock Production Science. 53: $135-142$

Lopez-Serrano, M.-Reinsch, N.-Looft, H.-Kalm, E. (2000): Genetic correlations of growth, backfat thickness and exterior with stayability in large white and landrace sows. Livestock Production Science. 64: 121-131.

Lucia, T.-Dial, G. D.-Marsh, W. E. (2000): Lifetime reproductive and financial performance of female swine. Journal of the American Veterinary Medical Association. 216. 11: 1802-1809.

Nagy I.-Csató L.-Farkas J.-Radnóczi L.-Vígh Zs. (2002): A magyar nagy fehér hússertés és magyar lapálysertés központi hízékonyság-vizsgálatának (HVT) elemzése túlélés becslés (survival analysis) alkalmazásával. Agrártudományi Közlemények. 9: 37-40.

Patterson, J. L.-Beltranena, E.-Foxcroft, G. R. (2010): The effect of gilt age at first estrus and breeding on third estrus on sow body weight changes and long-term reproductive performance. Journal of Animal Science. 88. 7: 2500-2513.

Pluym, L.-Van Nuffel, A.-Maes, D. (2013): Treatment and prevention of lameness with special emphasis on claw disorders in grouphoused sows. Livestock Science. 156: 36-43.

Rodriguez-Zas, S. L.-Southey, B. R.-Knox, R. V.-Connor, J. F.Lowe, J. F.-Roskamp, B. J. (2003): Bioeconomic evaluation of sow longevity and profitability. Journal of Animal Science. 81. 12: 2915-2922.

Rodriguez-Zas, S. L.-Davis, C. B.-Ellinger, P. N.-Schnitkey, G. D.Romine, N. M.-Connor, J. F.-Knox, R. V.-Southey, B. R. (2006): Impact of biological and economic variables on optimal parity for replacement in swine breed-to-wean herds. Journal of Animal Science. 84. 9: 2555-2565.

Schukken, Y. H.-Buurman, J.-Huirne, R. B. M.-Willemse, A. H.Vernooy, J. C. M.-van den Broek, J. (1994): Evaluation of optimal age at first conception in gilts from data collected in commercial swine herds. Journal of Animal Science. 72: $1387-1392$
Serenius, T.-Stalder, K. J. (2004): Genetics of length of productive life and lifetime prolificacy in the Finnish Landrace and Large White pig populations. Journal of Animal Science. 82: 3111-3117.

Serenius, T.-Stalder, K. J. (2007): Length of productive life of crossbred sows is affected by farm management, leg conformation, sow's own prolificacy, sow's origin parity and genetics. Animal. 1. 5: 745-750.

Sobczyńska, M.-Blicharski, T.-Tyra, M. (2014): A canonical correlation analysis of relationships between growth, compositional traits and longevity, lifetime productivity and efficiency in polish landrace sows. Annals of Animal Science. 14. 2: 257-270.

Stalder, K. J.-Lacy, R. C.-Cross, T. L.-Conatser, G. E. (2003): Financial impact of average parity of culled females in a breed-to-wean swine operation using replacement gilt net present value analysis. Journal of Swine Health Production. 11. 2: 69-74.

Stalder, K. J.-Knauer, M.-Baas, T. J.-Rothschild, M. F.-Mabry, J. W. (2004): Sow longevity. Pig News and Information. 25: 1N-22N

Stalder, K. J.-Saxton, A. M.-Conatser, G. E.-Serenius, T. V. (2005): Effect of growth and compositional traits on first parity and lifetime reproductive performance in U.S. Landrace sows. Livestock Production Science. 97. 2-3: 151-159.

Stein, T. E.-Dijkhuizen, A.-D’Allaire, S.--Morris, R. S. (1990): Sow culling and mortality in commercial swine breeding herds. Preventive Veterinary Medicine. 9: 85-94.

Sterning, M.-Rydhmer, L.-Eliasson-Selling, L. (1998): Relation ship between age at puberty and interval from weaning to oestrus and between oestrus signs at puberty and after the first weaning in pigs. Journal of Animal Science. 76: 353-359.

Tarrés, J.-Tibau, J.-Piedrafita, J.-Fabrega, E.-Reixach, J. (2003): Factors affecting longevity in maternal Duroc swine lines. Proc. $54^{\text {th }}$ Annu. Meet. Euro. Assoc. Anim. Prod. Rome. Italy.

Tarrés, J.-Tibau, J.-Piedrafita, J.-Fàbrega, E.-Reixach, J. (2006a) Factors affecting longevity in maternal Duroc swine lines. Livestock Science. 100. 2-3: 121-131.

Tarrés, J.-Bidanel, J. P.-Hofer, A.-Ducrocq, V. (2006b): Analysis of longevity and exterior traits on Large White sows in Switzerland. Journal of Animal Science. 84. 11: 2914-2924.

Tholen, E.-Bunter, K. L.-Hermesch, S.-Graser, H. U. (1996): The genetic foundation of fitness and reproduction traits in Australian pig populations 2. Relationships between weaning to conception interval, farrowing interval, stayability and other common reproduction and production traits. Australian Journal of Agricultural Research. 47: 1275-1290.

Xue, J. L.-Dial, G. D.-Marsh, W. E.-Lucia, T. (1997): Association between lactation and sow reproductive performance and longevity. Journal of the American Veterinary Madical Association. 210: 935-938.

Yazdi, M. H.-Lundeheim, N.-Rydhmer, L.-Ringmar-Cederberg, E.Johansson, K. (2000a): Survival of Swedish Landrace and Yorkshire sows in relation to osteochondrosis: a genetic study. Animal Science. 71. 1: 1-9.

Yazdi, M. H.-Rydhmer, L.-Ringmar-Cederberg, E.-Lundeheim, N.Johansson, K. (2000b): Genetic study of longevity in Swedish Landrace sows. Livestock Production Science. 63. 3: 255-264. 